\title{
Treatment of Malignant Hypertension with Infusion of Sodium Chloride; A Case Report and a Review
}

\author{
Hiroshi Kaneda, Toshiaki Yamauchi, Toyoaki Murata, \\ Jun Matsumoto and Takeshi Haruyama* \\ Clinic of Renal Disease, Iwaki-Kyoritsu General Hospital, \\ Iwaki 973, and ${ }^{*}$ Clinic of Internal Medicine, Joban City \\ Hospital, Iwaki 972
}

\begin{abstract}
Kaneda, H., Yamadchi, T., Murata, T., Matsumoto, J. and Haruyama, T. Treatment of Malignant Hypertension with Infusion of Sodium Chloride; $A$ Case Report and a Review. Tohoku J. exp. Med., 1980, 132 (2), 179-186 A man, now 46 years of age, $159 \mathrm{~cm}$ in height and $39 \mathrm{~kg}$ in weight, was diagnosed five years ago as essential hypertension with hypertensive nephropathy. On that occasion, renovascular stenosis was ruled out angiographically. Recently, he developed malignant hypertension and was admitted to our hosptial. On admission, severe hypertension $(260 / 160 \mathrm{mmHg})$, hyponatremia (132 $\mathrm{mEq} / \mathrm{liter}$ ), high reninemia $(40.0 \mathrm{ng} / \mathrm{ml}$; normal, $5.0-30.0 \mathrm{ng} / \mathrm{ml})$, high serum aldosterone level $(840 \mathrm{pg} / \mathrm{ml}$; normal, $10-100 \mathrm{pg} / \mathrm{ml})$ and advanced retinal changes $(\mathrm{KW}$. III) were found. He lost $10 \mathrm{~kg}$ in weight during the preceding 3 months. Other characteristic laboratory findings were hypopotassemia $(3.8 \mathrm{mEq} / \mathrm{liter})$, hypochloremia (85 mEq/liter), slight alkalosis, high serum lactate dehydrogenase level, increased cardio-thoracic ratio, and mild azotmia (BUN-46 mg/100 ml, serum creatinine- $3.8 \mathrm{mg} / 100 \mathrm{ml}$ ). As a therapeutic trial, $\beta$-blocker and hydralazine were administered, but no improvement was obtained. Then, sodium was infused in a dose of $328 \mathrm{mEq}$ dissolved in $1,500 \mathrm{ml}$ water in a time period of $12 \mathrm{hr}$. One $\mathrm{hr}$ after the start of sodium supplementation, his blood pressure was dramatically decreased to $174 / 120 \mathrm{mmHg} ; 3 \mathrm{hr}$ after the infusion, the blood pressure was $140 / 90 \mathrm{mmHg}$; one $\mathrm{hr}$ after the end of the infusion, the blood pressure remained as low as $130 / 90 \mathrm{mmHg}$. At the end of the infusion, serum sodium rose to 141 $\mathrm{mEq} /$ liter, PRA decreased to $8.0 \mathrm{ng} / \mathrm{ml}$, serum aldosterone level fell to $250 \mathrm{pg} /$ $\mathrm{ml}$, urinary sodium excretion decreased, and body weight increased by $1.5 \mathrm{~kg}$. From these findings, it seems likely that in this patient extreme hypertension caused an excessive diuresis resulting in fluid and sodium depletion in the body; the latter, in turn, eliciting further increase in renin release and blood pressure elevation. It may be concluded that malignant hypertension with hyponatremia and emaciation is an indication of parenteral sodium supplementation, and that the most important in the control of malignant hypertension is to keep the sodium balance in an appropriate range. -__- malignant hypertension; sodium supplementation
\end{abstract}

In 1914 Vorhard and Fahr had proposed malignant hypertension as a new clinical syndrome characterized by severe diastolic hypertension, advanced retinal changes, progressive renal damage and rapid progression of the disease frequently

Received for publication, July 18, 1979. 
resulting in death by cardiac decompensation, cerebrovascular accident, and renal failure.

In Japan, the ministry of public welfare had recommended the following criteria for the diagnosis of malignant hypertension; Group A. 1. Diastolic hypertension (constantly higher than $130 \mathrm{mmHg}$ ) 2. Papilledema 3. Advanced renal damage 4. Poor general conditions accompanied by heart failure or hypertensive cerebrovascular symptoms. Group B. Three of the 4 items mentioned above are positive, and the remaining one falls a little bit short of the criterium.

We are diagnosing the malignant hypertension according to the criteria mentioned above and elevated plasma renin activity (PRA).

We have experienced a patient with malignant hypertension accompanied by hyponatremia, high reninemia, high serum aldosterone level, and loss of body weight, and treated him successfully by parenteral administration of sodium chloride.

The purpose of this paper is to report this case and review the literature.

\section{Case Report}

The patient was a 41 years old man who admitted first on Feb. 21, 1973 in our hosptial complaining nausea, proteinuria, and hypertension. In his past history, he had been treated for pulmonary tuberculosis for 3 years. One of his brothers had mild hypertension, but other relatives and his parents had no hypertension.

On his first admission, his blood pressure was $180 / 100 \mathrm{mmHg}$, and physical examination revealed no particular findings; body weight was $50 \mathrm{~kg}$ and height was $159 \mathrm{~cm}$. Table 1 shows the laboratory data on his first admission, together with those at the second admission in 1978, and those after the treatment. At the first admission, slight anemia and proteinuria were noted, but serum creatinine, blood urea nitrogen and plasma renin activity (PRA, normal range; $5.0-30.0 \mathrm{ng} / \mathrm{ml}$ ) were within normal ranges. Soon after the admission, spironolactone, clonidine, and $\alpha$ methyl dopa were administered. Responding to these medications, his blood pressure fell to almost normal range. Renal angiography was performed, but no abnormalities were found. On April 27, 1973 he was discharged from our hosptial. Thereafter, he did not visit any hosptials stopping all the medications.

From January 1978, he felt general fatigue and lost body weight, and in Mar. violent headache and visual disturbance appeared. On March 11, 1978, now 46 years old, he visited our hospital to be admitted again. Prior to the second admission, he lost $10 \mathrm{~kg}$ of his body weight in the preceding 3 months. On his second admission, severe hypertension $(260 / 160 \mathrm{mmHg})$ was found. Prominent laboratory data (Table 1) were hyponatremia (132 $\mathrm{mEq} /$ liter), deteriorated renal function (Ccr-17.2 $\mathrm{ml} / \mathrm{min})$, high reninemia $(40.0 \mathrm{ng} / \mathrm{ml})$, elevated serum aldosterone concentration $830 \mathrm{pg} / \mathrm{ml}$; PAC, normal $(10-100 \mathrm{pg} / \mathrm{ml})$, and advanced retinal changes (KW-III). From these results, the diagnosis of malignant hypertension was made.

At first he was so anorectic that he could not eat or drink anything. Intravenous hyperalimentation was done. $\beta$-Blocker (pindolol, $20 \mathrm{mg} / \mathrm{day}$ ) and 
Table 1. Clinical data of the patient

\begin{tabular}{|c|c|c|c|c|}
\hline & $2 / 73$ & $11 / 3 / 78$ & $14 / 3 / 78$ & $11 / 5 / 79$ \\
\hline Weight (kg) & 50.0 & 38.0 & 39.5 & 45.0 \\
\hline Blood pressure (mmHg) & $180 / 100$ & $260 / 160$ & $130 / 90$ & $140 / 90$ \\
\hline Hemoglobin $(\mathrm{g} / 100 \mathrm{ml})$ & 12.8 & 11.0 & 9.1 & 10.4 \\
\hline $\begin{array}{l}\text { Serum sodium concentration } \\
(\mathrm{mEq} / \text { liter })\end{array}$ & 143 & 132 & 140 & 139 \\
\hline $\begin{array}{l}\text { Serum potassium concentration } \\
(\mathbf{m E q} / \mathrm{liter})\end{array}$ & 3.9 & 3.8 & 4.6 & 5.0 \\
\hline $\begin{array}{l}\text { Serum chloride concentration } \\
(\mathrm{mEq} / \text { liter })\end{array}$ & 105 & 85 & 103 & 105 \\
\hline Blood urea $(\mathrm{mg} / 100 \mathrm{ml})$ & 13.1 & 46.0 & - & 29.7 \\
\hline Serum creatinine $(\mathrm{mg} / 100 \mathrm{ml})$ & 0.9 & 3.3 & - & 2.0 \\
\hline Creatinine clearance $(\mathrm{ml} / \mathrm{min})$ & 96.0 & 17.2 & - & - \\
\hline $\begin{array}{l}\text { Lactate dehydrogenase } \\
\text { (Wroblewski units) }\end{array}$ & 440 & 980 & - & 136 \\
\hline Plasma renin activity $(\mathrm{ng} / \mathrm{ml})$ & 10.0 & 40.0 & 8.0 & 44.8 \\
\hline $\begin{array}{l}\text { Plasma aldosterone concent- } \\
\text { ration }(\mathrm{pg} / \mathrm{ml})\end{array}$ & - & 830 & 250 & - \\
\hline Retinal changes (Keith-Wagener) & I & III & - & $\mathrm{I}$ \\
\hline Cardiothoracic ratio $(\%)$ & 47.0 & 60.0 & - & 48.0 \\
\hline
\end{tabular}

hydralazine ( $80 \mathrm{mg} /$ day) were administered, but no effect was obtained. On the first hosptial day he received no sodium infusion, but he excreted $62 \mathrm{mEq}$ of sodium in the urine. On the second day the quantity of sodium infused was 30 $\mathrm{mEq}$, excreted was $61 \mathrm{mEq}$. Since the oral intake of food was negligible in these days, the sodium balance was strongly negative. The hyponatremia, elevated PRA, and high level of plasma aldosterone were to be explained by the negative sodium balance. Sodium supplementation seemed to be imperative to improve his condition. On the third day sodium chloride was infused at a dose of $328 \mathrm{mEq}$ in $1,500 \mathrm{ml}$ water in $12 \mathrm{hr}$ (Fig. 1). Before this treatment, his blood pressure was $190 / 160 \mathrm{mmHg}$. One $\mathrm{hr}$ after the start of sodium supplementation, the blood pressure fell dramatically to $174 / 120 \mathrm{mmHg} ; 3 \mathrm{hr}$ after the infusion, to $140 / 90$ $\mathrm{mmHg} ; 4 \mathrm{hr}$ after, to $160 / 100 \mathrm{mmHg} ; 6.5 \mathrm{hr}$ after, to $140 / 100 \mathrm{mmHg} ; 10 \mathrm{hr}$ after, to $150 / 110 \mathrm{mmHg}$, and one $\mathrm{hr}$ after the end of the infusion, to $130 / 90 \mathrm{mmHg}$. At the end of infusion, serum sodium concentration increased from $132 \mathrm{mEq} / \mathrm{liter}$ to $141 \mathrm{mEq} /$ liter, PRA decreased from 46.0 to $8.0 \mathrm{ng} / \mathrm{ml}$, serum aldosterone level fell from $800 \mathrm{pg} / \mathrm{ml}$ to $250 \mathrm{pg} / \mathrm{ml}$. Urinary sodium excretion decreased from $62.4 \mathrm{mEq} / 24 \mathrm{hr}$ on the preceding day to $24.0 \mathrm{mEq} / 24 \mathrm{hr}$ on the infusion day, urinary volume also decreased from $1,040 \mathrm{ml} /$ day on the preceding day to 300 $\mathrm{ml} /$ day on the infusion day, and body weight increased by $1.5 \mathrm{~kg}$ in $12 \mathrm{hr}$.

Since March 13 (the third hosptial day) to April 4 intravenous sodium supplementation (100-300 mEq/day) were done and $\beta$-blocker (pindolol, $20 \mathrm{mg} /$ day) was administered. In this period of time, his blood pressure fluctuated between 130 and $220 \mathrm{mmHg}$ (mean $187.5 \mathrm{mmHg}$ ) systolic, and between 90 and $140 \mathrm{mmHg}$ (mean $113.9 \mathrm{mmHg}$ ) diastolic. His body weight varied between 43.5 and 48.0 $\mathrm{kg}$ (mean of $44.9 \mathrm{~kg}$ ). On March 30 his serum sodium concentration was 140.0 


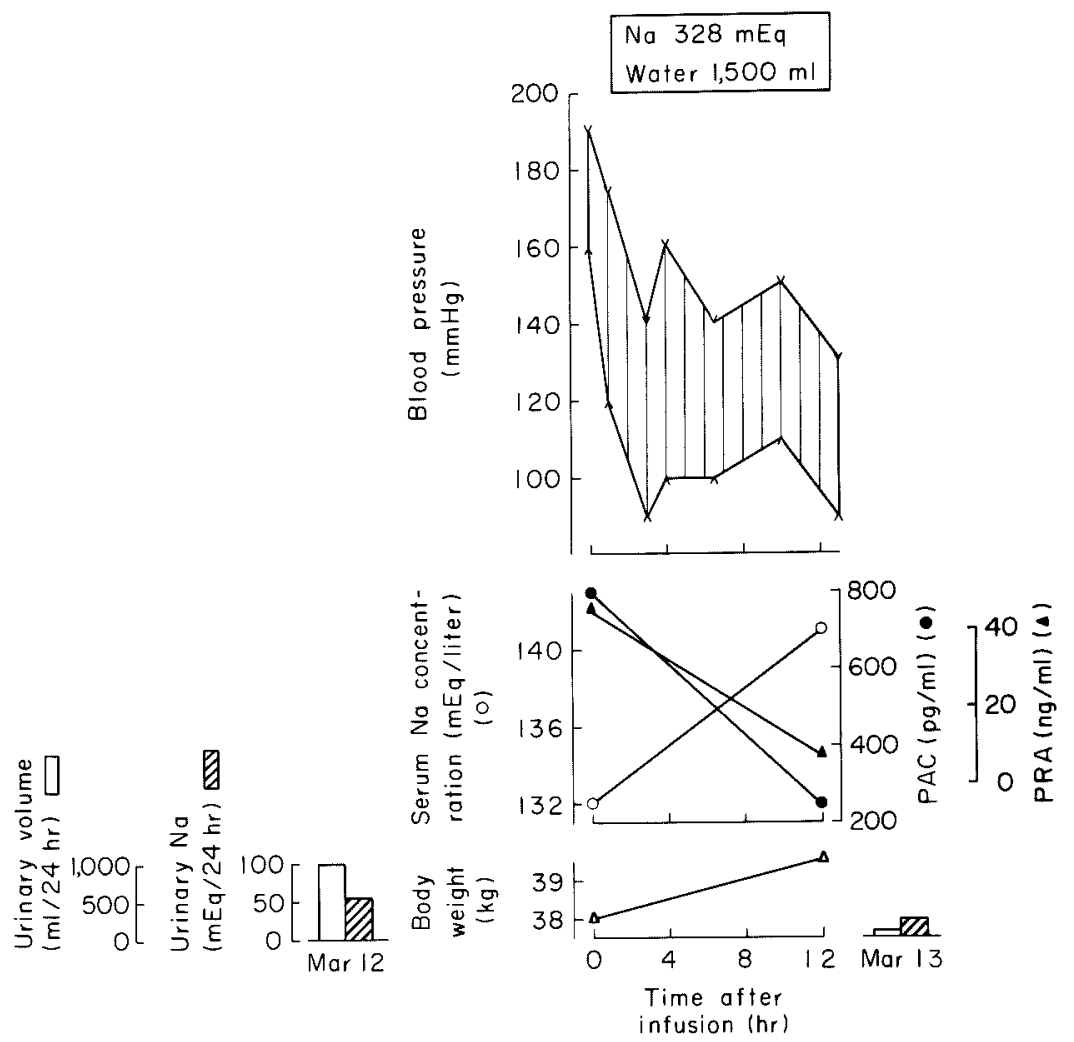

Fig. 1. Effects of sodium supplementation on blood pressure, serum sodium concentration,

PRA, PAC, urine volume, urinary sodium excretion, and body weight

$\mathrm{mEq} /$ liter, potassium was $4.5 \mathrm{mEq} /$ liter, $\mathrm{PRA}$ was $39.0 \mathrm{ng} / \mathrm{ml}$, and PAC was 215 $\mathrm{pg} / \mathrm{ml}$.

On April 4 intravenous sodium infusion was discontinued and since April 22 pindolol $(20 \mathrm{mg} /$ day) was replaced by propranolol $(60 \mathrm{mg} /$ day), but the blood pressure $(189.4 / 115.0 \mathrm{mmHg})$ remained unchanged. On May $4 \alpha$-methyl dopa (1,000 $\mathrm{mg} /$ day) was added to the propranolol with no remarkable effects. From June 19 propranolol was increased to $120 \mathrm{mg}$ per day, and concomitantly nifedipine $(80 \mathrm{mg} /$ day) was administered. Thereafter, the blood pressure fell and remained at a low level of 140.8-144.0/88.2-98.0 $\mathrm{mmHg}$, and his body weight was stabilized at $44.0-45.0 \mathrm{~kg}$.

On July 14 his serum sodium concentration was $145.0 \mathrm{mEq} /$ liter, potassium 3.5 $\mathrm{mEq} /$ liter, blood urea nitrogen $56.4 \mathrm{mg} / 100 \mathrm{ml}$, and serum creatinine level 2.1 $\mathrm{mg} / 100 \mathrm{ml}$. He felt quite well and then, on July 22, he was discharged from the hosptial. Most recent laboratory data (Table 1) on May 11, 1979 showed almost normal blood pressure $(140 / 90 \mathrm{mmHg})$, normal serum electrolytes, slight anemia, normal eye grounds, and slight elevation of blood urea and serum creatinine levels. He had no discomfort physically. 
Observation on PRA, PAC and electrolytes

Since March 11-31, serum sodium and potassium concentrations, PRAs, PACs, urine volume, urinary sodium excretion, and mean blood pressures were measured every day.

PRA (Abe et al. 1972) and PAC (Ogihara et al. 1977) were analysed by radioimmunoassay.

Statistical analysis was done as listed in Table 2. Mean blood pressure was significantly correlated with urine volume $(r=0.652, p<0.001)$ and urinary sodium excretion $(r=0.599, p<0.001)$. PRA was also significantly correlated with serum sodium concentration $(r=-0.477, p<0.05)$ and PAC $(r=0.980, p<0.001)$; the latter had a slight correlationship with serum potassium concentration $(r=-0.399$, $p<0.1$ ). Serum sodium concentration was also significantly correlated with serum potassium concentration $(r=0.603, p<0.001)$.

TABLE 2. Correlation coefficient and level of significance among mean blood pressure, $P R A, P A C$, serum sodium concentration, and serum potassium concentration

\begin{tabular}{|c|c|c|}
\hline $\begin{array}{l}\text { Number of } \\
\text { examinations }\end{array}$ & $\begin{array}{c}\text { Correlation } \\
\text { eoefficient } \\
(r)\end{array}$ & $\begin{array}{c}\text { Level of } \\
\text { significance } \\
(p)\end{array}$ \\
\hline \multicolumn{3}{|l|}{ I. Mean blood pressure } \\
\hline Urine volume $(\mathrm{ml} / \mathrm{day})$ & 0.652 & $<0.001$ \\
\hline Urinary sodium (mEq/day) & 0.599 & $<0.001$ \\
\hline \multicolumn{3}{|l|}{ II. Plasma renin activity $(\mathrm{ng} / \mathrm{ml})$} \\
\hline \\
\hline Serum sodium concentration (mEq/liter) 20 & -0.477 & $<0.05$ \\
\hline $\begin{array}{l}\text { Plasma aldosterone concentration } \\
(\mathrm{pg} / \mathrm{ml})\end{array}$ & 0.980 & $<0.001$ \\
\hline \multicolumn{3}{|l|}{ III. Plasma aldosterone concentration ( $\mathrm{pg} / \mathrm{ml})$} \\
\hline \multicolumn{3}{|l|}{$\begin{array}{l}\text { vs. } \\
\text { Serum potassium concentration ( } \mathrm{mEq} / \text { liter) }\end{array}$} \\
\hline $\mathrm{r}$ - & -0.399 & $<0.1$ \\
\hline \multicolumn{3}{|l|}{ IV. Serum sodium concentration ( $\mathrm{mEq} /$ liter) } \\
\hline \multicolumn{3}{|l|}{$\begin{array}{l}\text { vs. } \\
\text { Serum potassium concentration ( } \mathrm{mEq} / \text { liter) }\end{array}$} \\
\hline Ner una porawarase & 0.603 & $<0.001$ \\
\hline
\end{tabular}

\section{Discussion}

Sodium supplementation as a treatment of malignant hypertension is not popular and scarce in the literature (Kramer et al. 1974). But its usefullness was reported in experimental animals by Möhring et al. (1975a, b, 1976).

In patients with severely deteriorated renal function, sodium supplementation was usually believed to be hazordous because of acceleration of hypertension and overhydration leading to cardiac decompensation.

In our dialysis unit, we noted that too enthusiastic dialysis frequently caused hyponatremia (Kramer et al. 1974), high reninemia (Kaneda et al. 1979a, b), and uncontrollable hypertension as a result of excessive removal of sodium and water. 
These symptoms were reversible by the restoration of sodium and water balance. The malignant hypertension syndrome is usually accompanied by a negative sodium balance and high reninemia. Sodium supplementation seems to be a reasonable treatment in this syndrome. We tried and proved the effectiveness of the sodium infusion in a patient with malignant hypertension as reported above.

From these results, the following discussions seem to be warranted.

Onset of malignant hypertension and its mechanism. In the patient presented here, the characteristic clinical features were severe hypertension, hyponatremia, high reninemia, hypopotassemia, high serum aldosterone level, and pronounced emaciation. He lost $10 \mathrm{~kg}$ of his body weight during the preceding 3 months. The malignant hypertension in this patient might be brought about by a high degree of sodium depletion.

In this respect, Möhring et al. (1975 a, b) reported in experimentally produced unilateral renal artery stenosis in rats that the onset of malignant hypertension was primarily related to a critical level of blood pressure, and secondarily to excess sodium and water loss as a result of pressure diuresis. Barraclough (1966) also reported in man with right renal artery stenosis that acute progressive rise in blood pressure and excess renin production were responsible for the renal sodium and water wasting.

To sum up, both Möhring et al. (1975a, b) and Barraclough (1966) emphasized that the exsistence of unilateral renal artery stenosis is essential for the onset of malignant hypertension, regarding the excess sodium and water excretion as a secondary phenomenon.

In our case, however, renal artery stenosis was not recognized by renal angiography 5 years ago. In our dialysis unit, 4 patients developed the syndrome of malignant hypertension during the dialysis course as a result of too much removal of sodium and water.

Ten patients with malignant hypertension were studied histologically regarding the renal changes (5-biopsy, 5-autopsy), but none had arterial stenosis in renal arteries or their branches. Renovascular stenosis does not seem to be essential for the onset of malignant hypertension.

In the patient reported here, it was likely that the anorexia and hypertension caused a negative balance of sodium, the latter, in turn, producing the syndrome of malignant hypertension, even though he had not renovascular stenosis.

Möhring et al. (1976) reported that malignant hypertension in rats was improved by sodium supplementation, but not by water replacement alone.

Relationship between blood pressure, serum sodium concentration, and $R-A-A$ system. In the course of 21 days of hospitalization, the mean blood pressure changed in a statistically significant correlationship with urine volume and urinary sodium excretion, suggesting that the urine volume and urinary sodium excretion might be dependent on the blood pressure itself. This fact accords with the Möhring's experimental results (Möhring et al. 1975a, b, 1976) in rats and Barraclough's hypothesis (1966) that acute critical rise in blood pressure (higher 
than $180 \mathrm{mmHg}$ in rats) results in excess sodium and water excretion. As mentioned above, they believed that the acute critical rise in blood pressure is a principal factor eliciting the malignant hypertension.

It was also found in the present patient that PRA was highly correlated with $\mathrm{PAC}$, and negatively correlated with serum sodium level, suggesting that the R-A-A system is stimulated mainly by the negative sodium balance due to excessive sodium loss through the kidney.

Indication of sodium supplementation in malignant hypertension. Sodium supplementation is not always effective in the treatment of malignant hypertension. We have experienced 30 patients of malignant hypertension (21 dialysed, 9 non-dialysed) for the past 7 years. After the success of sodium therapy in the patient presented here, we tried it again in several other patients, but the results were not so excellent.

From these experiences, it may be concluded that the indication of sodium therapy should be limited to patients in a strongly negative sodium balance as evidenced by remarkable hyponatremia, high reninemia, hyperaldosteronism, and progressive weight loss.

The sodium supplementation should also be limited in a short periods of time to restore the patient's sodium status to normal, because prolonged sodium administration may have a danger to elicit a volume-dependent hypertension.

\section{Acknowledgment}

We gratefully acknowledge Professor Kaoru Yoshinaga, the Second Department of Internal Medicine, Tohoku University School of Medicine, Sendai, for his advice in preparing this manuscript. Our thanks are also due to Dr. Yasuo Hatakeyama, Director of Iwaki-Kyoritsu General Hospital, Iwaki and Dr. Nobuhide Mimura, Director of the Department of Nephrology, Toranomon General Hospital, Kanagawa.

\section{References}

1) Abe, K., Otsuka, Y., Saito, T., Chin, B.S., Aoyagi, H., Miyazaki, S., Irokawa, N., Seino, M., Miura, Y., Ono, I., Minai, K., Kobayashi, K., Sato, T. \& Yoshinaga, K. (1972) Measurement of plasma renin activity by angiotensin I radioimmunoassay: a modification of Haber's method. Jap. Circulat. J., 36, 741-749.

2) Barraclough, M.A. (1966) Sodium and water depletion with acute malignant hypertension. Amer. J. Med., 40, 265-272.

3) Kaneda, H. Masato, T., Matsumoto, J., Haruyama, T., Murata, T. \& Abe, K. (1979a) Release of renal renin in patients under long-term dialysis treatment. Tohoku $J$. exp. Med., 127, 25-33.

4) Kaneda, H., Tashiro, M., Murata, T., Matsumoto, J., Takeuchi, M. \& Haruyama, T. (1979b) Factors influencing the release of renin in patients under chronic dialysis treatment. Tohoku J. exp. Med., 129, 177-182.

5) Kramer, P., Köthe, E. \& Scheler, F. (1974) Hyponatriämisch-Hypertone Krise. Klin. Wschr., 52, 787-791.

6) Möhring, J., Möhring, B., Nauman, H., Philippi, A., Homsy, E., Orth, H., Dauda, G., Hazda, S. \& Gross, F. (1975a) Salt and water balance and renin activity in renal hypertension of rats. Amer. $J$. Physiol., 228, $1847-1855$.

7) Möhring, J., Möhring, B., Petri, M., Haack, D. \& Hackenthal, E. (1975b) Studies on 
the pathogenesis of the malignant course of renal hypertension in rats. $K$ idney Intern., 8, 174-180.

8) Möhring, J., Petri, M., Szokol, M., Haack, D. \& Möhring, B. (1976) Effects of saline drinking on malignant course of renal hypertension in rats. Amer. J. Physiol., 230, 849-857.

9) Ogihara, T., Iinuma, K., Nishi, K. Arakawa, Y., Takagi, A., Kurata, K., Migai, K. \& Kumahara, Y. (1977) A non-chromatographic non-extraction radioimmunoassay for serum aldosterone. $J$. clin. Endocr., 45, 726-731.

10) Vorhard, F. \& Fahr, T. (1914) Die Brightsche Nierenkrankheit. Berlin, Julius Springer. 